УДК 354:4.053.9

\title{
Чинники розвитку комплексного механізму соціального захисту населення
}

\author{
B.B. $\triangle \mathrm{ABPYXIH}$ \\ Національна акалемія державного управління при Презилентові України, \\ м. Київ, Україна, E-mail: general@academy.gov.ua
}

\begin{abstract}
Авторське резюме
У статті проаналізовано чинники розвитку комплексного механізму соціального захисту населення. Обгрунтовано, що при узгодженості інтересів суб'єктів і об’єктів соціального захисту по вертикалі і горизонталі їх взаємодія дозволяє ефективно розвиватися в сучасних економічних умовах; концептуальні основи ефективного розвитку соціального захисту припускають наявність чіткої регламентації компетенцій за рівнями соціально-економічної системи суспільства; розподіл компетенцій за рівнями соціально-економічної системи суспільства базується на об'єктивному аналізі видів витрат суспільства; організаційно-правові основи підвищення ефективності даного механізму структурно і змістовно визначаються соціально-економічними передумовами.
\end{abstract}

Ключові слова: соціальний захист, соціальна політика, соціальне забезпечення, механізми соціального захисту, державне управління.

\section{Factors complex mechanism of social protection}

\author{
V.V. LAVRUKHIN \\ National academy for public administration under the President of Ukraine, \\ Kyiv, Ukraine, E-mail: general@academy.gov.ua
}

\begin{abstract}
The article analyzes the factors in the development of a comprehensive mechanism of social protection of the population. It is proved that when the consistency of the interests of the subjects and objects of social protection vertical and horizontal interaction allows to develop effectively in the current economic conditions, a conceptual framework for efficient development of social protection require a clear regulation of the competence levels of the socio-economic system of the company; the distribution of competencies across levels of socio-economic system of a society is based on an objective analysis of the expenses of the company; the legal basis for the improvement of the effectiveness of this mechanism is structurally and content are determined by the socio-economic conditions.

Key words: social protection, social policy, social security, social protection mechanisms, and public administration.
\end{abstract}

Постановка проблеми. Існуюча система соціального захисту населення недостатньо ефективна і призводить до банкрутства держави, чиї фінансові можливості не відповідають соціальним зобов'язанням. Можна констатувати, що на сьогодні не забезпечується повною мірою виконання Конституції України, в якій Україна визначається як соціальна держава, адже відбувається суттєве зниження життєвого рівня основної маси населення.

Реформування соціального захисту визначено у Стратегії сталого розвитку - 2020 одним з першочергових пріоритетів. Незаперечним є факт необхідності вдосконалення механізмів соціального захисту для всіх груп населення. Визначення потенційних основних напрямів, структури і форм модернізації цих механізмів має досить актуальне теоретичне і практичне значення для сучасного етапу розвитку суспільства.

Аналіз досліджень i публікацій. Важливі аспекти формування та розвитку сучасної системи соціального захис(C) В.В. Лаврухін, 2015 
ту населення в Україні висвітлюються в роботах Е. Гансової, С. Горбатюк, В. Єлагіна, О. Кілієвича, М.Кравченко, К. Міщенко, Я. Радиша, І. Розпутенка, О. Романюк, I. Солоненка, В. Толуб'яка, I.Хожило, П. Шевчука, Н. Ярош та ін.

Однак при всій значущості даних досліджень вони здебільшого зосереджені на правових, економічних аспектах соціального захисту, залишаючи без розгляду саме модернізацію сформованих механізмів у цій сфері, що й обумовило вибір теми даного дослідження.

Метою дослідження є обгрунтування чинників розвитку комплексного механізму соціального захисту населення в Україні в сучасних умовах.

Виклад основного матеріалу. Виявлення чинників розвитку комплексного механізму є найважливішою передумовою поступального розвитку соціального захисту в цілому. Раніше нами були визначені типи структур соціального захисту залежно від міри участі держави i суб’єктів господарювання, засновані на трьох варіантах розвитку суспільного виробництва (простому, розширеному, деграційному). На основі цієї класифікації більшість вітчизняних і зарубіжних авторів виділяють внутрішні, зовнішні і змішані чинники управління. Ця класифікація відображає реальний процес взаємодії складових елементів. Найбільш оптимальним вважається розгляд внутрішніх і зовнішніх чинників 3 позицій вхідного і висхідного потоку, його швидкості і інтенсивності [1].

У соціальному захисті зовнішніми чинниками є: норми права, організація управління. До внутрішніх чинників відносяться: кваліфікація кадрів, матеріально-технічна база, внутрішня система організації і внутрішні акти управління.

Також виділені рівні соціально-економічної системи дозволяють структурувати чинники по горизонталі і вертикалі на: державні, регіональні, місцеві, сімейні і одиничні (рівень члена сім'ї).

Таке виділення служить об'єктивною основою, оскільки дозволяє розкрити повторюваність, тенденції розвитку i аналогію у вирішенні поставлених зав- дань. Всі ці чинники впорядковані за трьома соціально-економічними критеріями: «ресурси - результати»; «види соціального захисту - споживання»; «цикли і фази суспільного відтворення». Це дозволяє виділити основні групи чинників, які можна конкретизувати за змістом, спрямованістю дії, характером.

Виділення нижче означеної сукупності чинників дозволяє з системно-цілісних позицій прогнозувати зміни в комплексному механізмі соціального захисту, можливості своєчасного внесення поправок і усунення недоліків у функціонуванні системи соціального захисту. Крім того, всі існуючі чинники слід розглядати з позиції обігу модернізації системи соціального захисту. Вплив чинників об'єктивно змінюється за фазами циклу обігу модернізації соціального захисту, що відповідно вимагає вжиття адекватних заходів організаційного, економічного характеру для ефективного управління системою в цілому.

Такий підхід має універсальне значення і може бути адаптований до конкретного рівня соціально-економічної системи. Такий підхід, по-перше, підкреслює органічну єдність модернізації комплексного механізму соціального захисту населення; по-друге, припускає розгляд окремих чинників в їх динаміці і у взаємозв'язку з розвитком сукупності інших чинників по вертикалі і горизонталі їх руху.

Однією 3 найважливіших умов успішного рішення даного завдання $€$ узгодженість в часі і просторі, збалансованість перетворення всіх матеріально-речовинних, особистих, соціокультурних і соціальних чинників. Усі зазначені чинники знаходяться в певних відносинах 3 системою соціального захисту. Частина чинників змінює систему, частина зберігає незмінною. Це створює три варіанти впливу на систему - позитивний, негативний або нейтральний. Отже, чинники можна ранжувати за варіантом впливу, а також за виконанням соціально-економічних функцій, що дозволяє визначити сферу ï впливу. Аналіз чинників 3 позицій представленої таблиці дозволяє визна- 
чити найефективніші напрями, шляхи, форми і межі корисності і шкідливості для суспільства системи соціального захисту в цілому і окремого домогосподарства. Такий підхід дає можливість спочатку визначити перспективні, тупикові i неефективні розробки варіантів модернізації системи соціального захисту. Особливе значення має аналіз чинників з позицій основних варіантів стану системи соціального захисту. Тут є можливість визначити техніко-технологічні, соціально-економічні і духовноетичні рішення в управлінні соціальним захистом. Розрахунок стану чинників за основними варіантами стану системи соціального захисту дозволить виявити типові моделі і потім визначити кількісні і якісні характеристики напрямів перетворення системи на кожному рівні соціально-економічної системи. Характерною особливістю системи соціального захисту $є$ наявність специфічних чинників, таких як «людський капітал», в якому знаходять своє вираження соціальні ролі самої людини в соціальному захисті себе і сім’ї.

В одних і тих же соціально-економічних умовах з рівною дією ідентичної кількості чинників розвиток сім'ї може відбуватися по-різному. Врахування цієі обставини дозволить істотно просунутися у виробленні на мікрорівні стратегій соціального захисту окремої сім'ї. Як специфічні чинники участі населення в соціальному захисті на основі цілісного аналізу відтворювальних циклів визначимо наступні: а) формування системи загальнозначущих соціальних цінностей як реальних регуляторів соціального життя; б) використання наявних професійно-кваліфікаційних ресурсів, як стартового майданчика для підвищення соціальної мобільності.

Цикл соціальної діяльності сім’ї має важливе теоретичне i практичне значення для пізнання і використання в управлінні системою соціального захисту і підвищенні їі ефективності. Тут слід пам'ятати, що відтворювальні цикли, види соціального захисту - споживання, ресурси і цикли соціальної діяльності сім’ї, разом узяті, є початковими векто- рами моделювання механізму підвищення соціально-економічної ефективності соціального захисту. Існує органічний зв'язок між часом обігу модернізації чинників комплексного механізму, видами соціального захисту - потребами, витратою ресурсів і особливостями циклів соціальної діяльності сім'ї. Це дає ключ до впорядковування пізнання i управління процесом підвищення ефективності соціального захисту.

Соціальна діяльність сім'ї є найважливішим чинником розвитку соціального захисту в суспільстві. У кожному з циклів соціальної діяльності сім'ї між членом сім’ї і обігом модернізації соціального захисту встановлюється взаємовплив.

Кожний з видів соціальної діяльності $є$ специфічним чинником соціального захисту, від впливу якого залежить яким чином розвиватиметься система соціального захисту. На домінуючих раніше соціальних очікуваннях, заснованих на переконанні у тому, що держава покликана створити сприятливі умови життєдіяльності, сформувалося не одне покоління громадян. Це на сьогоднішній день значно впливає на формування системи соціального захисту. Тому перехід від менш гуманного стану системи соціального захисту до гуманнішого не можна форсувати, оскільки об'єктивно існує обіг модернізації соціального захисту (25 років) заснований на зміні поколінь. Перші 25 років людина проходить період особової і соціальної ідентифікації, в наступні 25 років створює інше покоління, в основі виховання якого знаходиться існуюча зараз ідеологія. Отже, зміна ідеологій можлива тільки через покоління. Відповідно, якщо зараз 7-8 стан соціального захисту, для переходу на новий якісний рівень необхідно змінити співвідношення впливу чинників комплексного механізму соціального захисту населення для позитивного розвитку соціального захисту [1].

Для низького рівня стану розвитку суспільства характерна недостатня увага держави i державних інститутів до соціального захисту населення; центр тяжіння зміщений на сім'ю і людину, 
відсутні державні компенсації; забезпечується не повний набір соціального захисту людини і суспільства; соціальний захист схильний до стихійних значних коливань і змін; у міру розвитку суспільства посилюється вплив держави i всіх рівнів соціально-економічної системи в соціальному захисті, центр зміщується від громадянина на всі подальші рівні соціально-економічної системи під контролем держави. Існує величезна кількість досліджень, які стосуються впливу розвитку суспільних відносин на самовизначення особистості і стратегію іiі життедіяльності.

Існує органічний зв'язок між часом обігу модернізації чинників комплексного механізму, витратою ресурсів, видами діяльності - споживання і тривалістю циклу модернізації системи соціального захисту суспільства. Це дає ключ до впорядковування пізнання i управління комплексним механізмом, підвищенням його ефективності.

Таким чином, представлений інструментарій дозволяє аналізувати чинники з урахуванням основних станів елементів соціального захисту, цілісної моделі, критеріїв, функцій та їх впливів на розвиток і реалізацію соціального захисту. Сім'я є ключовим об’єктом управління 3 боку соціального захисту, між ними виникають суб'єктно-об'єктні відносини, результатом яких $€$ якийсь продукт. В даний час спостерігається розузгодження між цілями, критеріями, структурою i формами діяльності суб'єкта, об'єкта управління, суб'єктно - об'єктними відносинами. В результаті не розв'язуються поставлені завдання по ефективному функціонуванню соціального захисту. Введення в аналіз методології системно-цілісного пізнання явищ дозволяє виявити кількісний і якісний вплив соціально - економічних чинників на соціальний захист, що в свою чергу дозволяє зробити наступний крок: перейти до питання формування соціально-економічних i організаційно-правових аспектів підвищення ефективності соціального захисту населення.

Кількісні і якісні зміни в розвитку продуктивних сил i виробничих відно- син, які спостерігаються на сучасному етапі, відповідно трансформують соціальний захист. У цьому зв'язку виникає об'єктивна необхідність формування адекватної концепції розвитку даної сфери життєдіяльності суспільства. Переважно поширені кількісний і ресурсний підходи до формування системи соціального захисту не відповідають належною мірою якісно новим завданням сучасного періоду.

Найважливішими соціально-економічними принципами даної концепції є: стимулювання ефективності управління соціальним захистом; встановлення державою пріоритетів, пов'язаних з соціальною захищеністю перш за все сім’ї як суспільного інституту; впровадження нової техніки і технології ефективного використання ресурсів; вкладення засобів у розвиток можливостей для сім'ї по самозабезпеченню; встановлення податкових пільг, митних тарифів; безпосередне надання фінансової допомоги державою і її структурними ланками по розробці і реалізації великих і високоперспективних програм соціального захисту недержавними установами.

В даний час у поняття «соціального захисту» вкладаються лише соціальний зміст і значення. Але будь-яке суспільне явище має цілком конкретний економічний вираз. Отже, доцільно говорити про соціально-економічні аспекти даної сфери. Відмінності мають принциповий характер, оскільки економічна складова орієнтує учасників соціального захисту на використання таких понять, як корисні i даремні витрати, резерви i втрати розвитку. А соціальна складова визначає цілу гамму цілей, проміжних результатів. Узяті окремо, вони спрямовують діяльність учасників соціального захисту на здійснення численних цільових установок, вироблення різних критеріїв, показників на кожному рівні суспільних відносин i, відповідно, носять деколи відомчий і проміжний характер. На відміну від цього соціально-економічні аспекти орієнтують на задоволення кінцевих потреб суспільства, території, окремої сім'ї і людини, інтегрують, ранжирують види діяльності і спожи- 
вання в соціальному захисті, націлюють учасників на комплексну результатив ність. Таким чином, соціально-економічні аспекти підвищення ефективності соціального захисту є основоположними засадами для формування ефективного механізму соціального захисту населення. Комплексний підхід до забезпечення ефективного управління соціальним захистом за рівнями соціально-економічної системи заснований на методології системно-цілісного пізнання даного явища. Такий підхід адекватно відображає всі процеси 3 міждисциплінарних позицій регулювання соціальних відносин в країні, роботи держави 3 населенням, що дозволяє сформувати об'єктивний моніторинг, який створить можливість враховувати в масштабі реального часу роботу, що проводиться, i своєчасно відображати поточні й майбутні недоліки. Крім того, комплексний підхід припускає застосування сучасних інформаційних технологій і орієнтування на використання напрацювань фундаментальних наук, зокрема виділенні корисних, даремних, шкідливих витрат, втрат і резервів для розвитку. В результаті $€$ можливість створити комплексний механізм соціального захисту стосовно територіально-галузевих і т.д. умов. Кожне із структурних положень органічно взаємозв'язане з усіх боків, тому розробка соціально-економічних основ захисту населення спочатку вестиметься в умовах визначеності, дозволяє виключити тупикові напрями, шляхи, форми, методи, організації даної сфери діяльності держави і підвищити відповідальність як суб'єктів управління, так і особисту відповідальність громадян.

Ідеологія, методологія і теорія концепції соціального захисту спираються на головну мету: забезпечення гідних умов життя i вільного розвитку всіх груп населення соціальної держави за допомогою проведення нею гуманної соціально-економічної політики, заснованої на чинних нормативно-законодавчих актах. Захисний механізм останньої припускає формування гідних умов для життєдіяльності окремо сім'ї і людини. Адаптація даної мети до конкретних умов припускає її відповідність визначеним критеріям і соціально-економічним функціям соціального захисту. При формуванні організаційної структури управління принципи, заявлені в ідеології, теорії методології повинні бути покладені в основу діяльності на всіх рівнях соціально-економічної системи суспільства.

Завдання концепції - розробити стратегію і тактику відповідно до загального ідеологічного принципу гуманного соціального захисту. Виконання соціально-економічних функцій відображається в критеріях і показниках. Ступінь результативності вживаної стратегії i тактики оцінюється як опосередкований розподіл компетенцій за рівнями соціально-економічної системи, виконання яких впливає на зростання корисних витрат, ефективність використання ресурсів, скорочення даремних, шкідливих витрат, втрат.

Розвиток організаційно-правової структури і компетенцій за рівнями соціально-економічної системи визначає порядок взаємовідносин за всіма аспектами концепції.

Розвиток технології соціального захисту заснований на принципах гуманності. Всі організаційні і технологічні перетворення вимагають розрахунків за видами витрат, з метою своєчасної діагностики і коригування розвитку системи соціального захисту. На цьому етапі особливо важливо точно визначити якому 3 дев'яти станів відповідають організаційна діяльність і технології соціального захисту. Часто в практиці використовуються технології, що не відповідають вимогам цілей першого положення. Це веде до виникнення суперечностей між очікуваним i фактичним результатами.

Наступна позиція - мотивація учасників соціального захисту. Розвиток соціальних послуг припускає задоволення потреб населення і створення стимулів до особистого розвитку і самозабезпечення. Багатогранність категорії і складність її комплексної розробки привели до того, що існуюча система соціального захисту має значні недоліки по даному положенню, що знижує ефективність 
системи в цілому. Подолати існуючі недоліки можна за умови використання запропонованих нами основних концептуальних положень відповідно до матриці, яка забезпечує ефективне управління соціальним захистом населення [2].

Розвиток інформаційного забезпечення соціального захисту виконує важливу роль. Характерним тут $є$ структуризація інформації за обліком, контролем, аналізом послуг, що надаються, 3 рівнів соціально-економічної системи 3 виділенням об'єктивних даних про керований процес.

Об'єктивними вимогами до інформації є: достатність і необхідність, своєчасність, відповідність тенденціям і темпам розвитку соціального захисту. Ефективне інформаційне забезпечення припускає використовування системно-цілісної моделі розвитку і управління, заснованої на відповідній методології пізнання.

У різних варіантах стан соціального захисту у вигляді співвідношення ресурсів і результатів відрізняються. Для переходу на вищий рівень суспільних відносин і соціального захисту потрібен постійний аналіз за видами ресурсних витрат, ефективності їх використання за рівнями соціально-економічної системи і результатами, головним з яких є підвищення добробуту населення. Це складає суть дев'ятого положення, яке задає орієнтири для всіх попередніх положень.

Виходячи 3 вищесказаного, соціально-економічні основи ефективного розвитку соціального захисту мають специфічні характеристики за рівнями соціально-економічної системи, вони обумовлюються структурою суспільного виробництва, відображають відповідні цілі, завдання, критерії, інтереси і закономірності розвитку соціального захисту на сучасному етапі. Розвиток концепції відбувається відповідно до фаз відтворювальних циклів соціального захисту, припускає діалектику розвитку ідеології і цілей соціального захисту за фазами відтворювального циклу суспільного виробництва. Звідси розроблена на цій основі концепція відображатиме всі рівні, форми, методи регулювання відносин по соціальному захисту.
На державному рівні соціально - економічні аспекти відображають відношення результатів до витрат в одиницю часу, які виникають у ході розподілу i перерозподілу для потреб соціального захисту готової продукції і послуг, створених за рахунок частини необхідного i вільного часу суспільства. Як початкова інформація беруться дані про кількість наданих послуг, чисельність соціально уразливих груп населення, витрати ресурсів на підтримку їх життєзабезпечення і результатах діяльності органів влади.

Ранжування витрат на корисні, даремні, шкідливі, резерви i втрати розвитку дозволяє визначити концептуальні основи і методологію можливих соціально - економічних змін на всіх рівнях соціально-економічної системи.

В період економічної кризи збільшення ресурсних вкладень обумовлює зміну співвідношень балансу сил в суспільному виробництві, що негативно позначається на перспективах розвитку країни в цілому. Залишається другий спосіб. В даному випадку необхідно проаналізувати порядок розподілу компетенцій, їх доцільність, яка в свою чергу визначається витратами суспільства 3 позиції загальноцивілізаційного підходу. Результати даного аналізу дозволяють зробити висновки про ефективність існуючої системи управління.

Аналіз учасників соціального захисту, ресурсів і їх діяльності з погляду корисності витрат дає можливість ранжувати і визначати об'єктивні шляхи, форми i методи ефективного розвитку учасників і використання ресурсів. Розгляд витрат ресурсів з позиції корисності для суспільства і суб'єкта соціального захисту в процесі розробки i реалізації конкретної концепції на додаток до вище відміченого, дозволяє конкретизувати і визначати кількісно позитивні, нейтральні і негативні управлінські рішення. Найточніше такий аналіз дозволяє провести концептуальна модель соціально - економічної оцінки витрат на функціонування системи управління. Використання даної моделі на практиці органами управління за 
рівнями соціально-економічної системи цілком обгрунтовано дозволяє керівнику оцінювати ефективність існуючої системи управління.

Висновок. Таким чином, по-перше, соціальний захист, здійснюваний на гуманних принципах і організаційно-правових формах відмічених вище здатний стати ефективною складовою суспільних відносин за рівнями соціально-економічної системи суспільства; по-друге, при раціональному підході - узгодженості інтересів суб'єктів і об'єктів соціального захисту по вертикалі і горизонталі їх взаємодія дозволяє ефективно розвиватися в сучасних економічних умовах; по-третє, концептуальні основи ефек- тивного розвитку соціального захисту припускають наявність чіткої регламентації компетенцій за рівнями соціально-економічної системи суспільства; по-четверте, розподіл компетенцій за рівнями соціально-економічної системи суспільства базується на об'єктивному аналізі видів витрат суспільства; поп'яте, закріплення в нормах права положень відповідно до концептуальних основ дозволить створити комплексний характер соціального захисту на основі системно-цілісного пізнання; по-шосте, організаційно-правові основи підвищення ефективності даного механізму структурно і змістовно визначаються соціально-економічними передумовами.

\section{СПИСОК АITЕРАТУРИ:}

1. Основні напрями оптимізації системи соціального захисту в Україні : аналіт. доп. / О. О. Кочемировська, О. М. Пищуліна. - К. : НІСД, - 2012. - 88 с.

2. Слезингер Г.Э. Социальная экономика: Учебник / Г.Э. Слезингер. М.: Изд-во Дело и Сервис, 2001. -368 c.

\section{REFERENCES:}

1. Osnovni napryamy optymizatsiyi systemy sotsial'noho zakhystu v Ukrayini : analit. dop. (The main directions of optimization of social protection in Ukraine: analyte. ext.). $-\mathrm{K}$. : NISD, $-2012 .-88 \mathrm{p}$

2. Slezinger G.E. Sotsialnaya ekonomika: Uchebnik (Social economy: Textbook). M.: Izd-vo Delo i Servis, 2001. - 368p.

Лаврухін Владислав В'ячеславович - аспірант

Національна академія державного управління при Президентові України Адреса: 03057, м. Київ, вул. Ежена Потьє, 20

E-mail: general@academy.gov.ua

Lavrukhin Vladyslav Vyacheslavovych - postgraduate

National academy for public administration under the President of Ukraine

Address: 20, Ezhena Pottier Str., Kyiv, 03057, Ukraine

E-mail: general@academy.gov.ua 